\title{
The Cooccurrence of Different Biflavonoid Types in Pilotrichella flexilis ${ }^{\S}$
}

\author{
Elke Brinkmeier, Hans Geiger and Hans Dietmar Zinsmeister*\$\$ \\ Fachrichtung Botanik, Universität des Saarlandes, Saarbrücken, BRD \\ $\$ \S$ Current address: Fasanenweg 2, 66133 Saarbrücken, Fax: 0681/812825 \\ Dedicated to Professor Hans Becker on the occasion of his $60^{\text {th }}$ birthday \\ * Author for correspondence and reprint requests \\ Z. Naturforsch. 55c, 866-869 (2000); received June 15/July 31, 2000 \\ Pilotrichella flexilis, 2,3,2",3"-Tetrahydrodicranolomin, Pilotrichellaaurone
}

From Pilotrichella flexilis various flavonoids have been isolated. This species contains in contrast to $P$. cuspidata not only $3^{\prime}, 3^{\prime \prime \prime}$-binaringenin and related compounds, but also some hitherto unknown biflavonoids based on eriodictyol and aureusidin. The structures of two new compounds are elucidated spectroscopically. Possible causes for the differences of the flavonoid patterns between the two species of the genus Pilotrichella are discussed.

\section{Introduction}

In continuation of our phytochemical investigations of bryophytes the flavonoid patterns of some mosses from Central America were surveyed by our standard 2 D-TLC methods (Geiger et al., 1997). In the course of this study it was observed that Pilotrichella flexilis exhibits a rare combination of flavonoid characters (Brinkmeier, 1996). This prompted us to study this moss in more detail.

\section{Results and Discussion}

Working up an extract from $280 \mathrm{~g}$ P. flexilis, as described in the experimental section, yielded three major (1, 5 and $\mathbf{6})$ and three minor compounds $(\mathbf{2}, \mathbf{3}$, and $\mathbf{4})$ in sufficient amounts to establish their structural identity. The yields of two further compounds were too low to establish their structures beyond doubt.

The compounds $\mathbf{1}, \mathbf{2}, \mathbf{3}$ and $\mathbf{4}$ turned out to be known compounds; they were identified by comparison of their NMR spectra with those of the authentic isolates from Pilotrichella cuspidata (Seeger et al., 1992) and Hypnum cupressiforme (Sievers et al., 1992 and 1994) as 3',3'-'binaringenin (1), hypnogenol A (2), hypnumaldehyde (3) $\left[=3,5,7,4^{\prime}\right.$-tetrahydroxy-3' -(3"-formyl-6"-hydroxyphenyl)-flavanone], and hypnum acid (4).

\footnotetext{
$\S$ Publication No. 151 of the Arbeitskreis Chemie und Biologie der Moose.
}

The compounds 5 and $\mathbf{6}$ turned out to be hitherto unknown biflavonoids; their exact structures were elucidated by comparing their NMR data with those of known biflavonoids having identical partial structures.

Compound $\mathbf{5}$ shows on TLC plates a spot which appears under U. V. light dark and becomes after spraying with diphenylboric acid $\beta$-aminoethylester after a few hours deep red like eriodictyol and biflavonoids that contain an eriodictyol moiety (Geiger et al., 1997). The FAB mass spectrum of 5 exhibits a $[\mathrm{M}-\mathrm{H}]^{-}$anion at $573 \mathrm{~m} / z$. These facts suggest that $\mathbf{5}$ is a bieriodictyol. A bieriodictyol contains two asymmetric carbons (C-2 and C-2') and possibly, due to restricted rotation round the interflavonyl-linkage, a third center of chirality (c. f. Geiger and Bokel, 1989). Thus a bieriodictyol may exist in four diastereomeric forms. The NMR spectra of $\mathbf{5}$ show, however, only a doubling, but no quadrupling of several signals. The reason might be either that only one of the three centers changes its chirality, whereas the other two retain their relative configuration, or that coincidence of signals prevents observation of quadruple signals. Nevertheless, a careful analysis of the ${ }^{1} \mathrm{H}$ and ${ }^{13} \mathrm{C}$ spectra of $\mathbf{5}$ by means of various correlation techniques $(\mathrm{H}-\mathrm{H}$ and $\mathrm{C}-\mathrm{H}$ COSY, ROESY and HMBC) allowed to assign each signal or pair of signals to a distinct position in a bieriodictyol linked via C-2' and C-6" (Brinkmeier, 1996). Table I shows the NMR data of $\mathbf{5}$, which are essential for the deduction of its structure: Multiplicity and chemical shift of the signals assigned to the 
<smiles>[R]C1C(=O)c2c(O)cc(O)cc2OC1c1ccc(O)c(-c2ccc(C)c(O)c2)c1</smiles>

$R=R^{\prime}=H:$ 3',3"'-Binaringenin (1)

$\mathbf{R}=\mathbf{R}^{\prime}=\mathbf{O H}$ : Hypnogenol A (2)<smiles>[R]c1ccc(O)c(-c2cc(C3Oc4cc(O)cc(O)c4C(=O)C3O)ccc2O)c1</smiles><smiles>[R]C=O</smiles>

$\mathrm{R}=\mathrm{COOH}:$ Hypnum acid (4)<smiles>O=C1CC(c2ccc(O)c(O)c2)Oc2cc(O)c(-c3c(O)c(O)c4c(c3O)OC(c3ccc(O)cc3)CC4=O)c(O)c21</smiles>

2,3,2",3"-Tetrahydrodicranolomin (5)

"left hand" eriodictyol moiety of $\mathbf{5}$ are almost identical with those of the corresponding eriodictyol moiety of 2,3-dihydrodicranolomin (Hahn et al., 1995) and 2,3-dihydro-3"'desoxydicranolomin (Rampendahl et al., 1996), whereas the signals attributed to the "right hand" differ only marginally from those of the eriodictyol part of campylopusaurone (Geiger and Markham, 1992; Geiger et al., 1993). Thus $\mathbf{5}$ is $2,3,2^{\prime \prime}, 3^{\prime \prime}$-tetrahydrodicranolomin.<smiles>O=C1C(=Cc2ccc(O)c(O)c2-c2c(O)cc3c(c2O)C(=O)C[C@H](c2ccc(O)c(O)c2)O3)Oc2cc(O)cc(O)c21</smiles>

Pilotrichellaaurone (6)

The spots of $\mathbf{6}$ and the two trace-compounds on TLC-sheets exhibit under U. V. light a strong bluish green fluorescence, which turns after spraying with diphenylboric acid $\beta$-aminoethylester to yellowish orange at first and becomes red after a few hours. This is characteristic of biflavonoids containing an aureusidin as well as an eriodictyol moiety (Geiger et al., 1997). The FAB mass spectra of all three compounds show $[\mathrm{M}-\mathrm{H}]^{-}$anions at 571 $\mathrm{m} / \mathrm{z}$, this suggests that they are all isomers differing only in the location of the interflavonyl linkage.

Compound 6 which shall be named pilotrichellaaurone, was isolated in a sufficient quantity to study its NMR spectra in every detail (Brinkmeier, 1996). Table I shows the ${ }^{1} \mathrm{H}$ and ${ }^{13} \mathrm{C}$ data that are necessary to deduce its structure by comparison with the data of known compounds: The signals of the eriodictyol moiety $\left(\mathrm{C} / \mathrm{H} 2^{\prime \prime}-6^{\prime \prime \prime}\right)$ are almost identical with the corresponding signals of $\mathbf{5}$, whereas number, multiplicity and chemical shift of the remaining signals are as expected for an aureusidin linked via its C-2' to C-6" of the eriodictyol (c. f. Geiger and Markham, 1992; Geiger et al., 1993). Thus the structure of pilotrichellaaurone (6) is proved. The yields of the two minor biflavonoids that seem to be isomers of $\mathbf{6}$ were too low to obtain all the NMR data, that are necessary to prove their exact structures beyond doubt. The available ${ }^{1} \mathrm{H}$ NMR data indicate, however, that they are hitherto unknown isomers of $\mathbf{6}$.

The cooccurrence of $\mathbf{1}, \mathbf{5}$ and $\mathbf{6}$ in almost equal amounts in $P$. flexilis is in sharp contrast to our 
Table I. Essential NMR data of 5 and $\mathbf{6}$ extracted from Brinkmeier (1996) bracketed multiplicities are ill defined, but evident from H-H COSY.

\begin{tabular}{|c|c|c|c|c|c|c|c|}
\hline \multirow{3}{*}{$\frac{\mathrm{C} / \mathrm{H}}{2}$} & \multicolumn{3}{|c|}{ 2,3,2",3"-Tetrahydrodicranolomin (5) } & \multicolumn{4}{|c|}{ Pilotrichellaaurone (6) } \\
\hline & ${ }^{13} \mathrm{C}$ & & & $\mathrm{C} / \mathrm{H}$ & ${ }^{13} \mathrm{C}$ & ${ }^{1} \mathrm{H}$ & \\
\hline & 77 & $\begin{array}{l}4.95 \mathrm{dd} \\
(2 / 12.5)\end{array}$ & $\begin{array}{l}4.93 \mathrm{dd} \\
(2 / 12.5)\end{array}$ & & & & \\
\hline $3 \mathrm{ax}$ & 43 & $\begin{array}{l}3.08 \mathrm{dd} \\
(12.5 / 17)\end{array}$ & $\begin{array}{l}3.06 \mathrm{dd} \\
(12.5 / 17)\end{array}$ & & & & \\
\hline eq & & $\begin{array}{l}2.47 \mathrm{dd} \\
(2 / 17)\end{array}$ & $\begin{array}{l}2.50 \mathrm{dd} \\
(2 / 17)\end{array}$ & $\alpha$ & 108 & $6.15 \mathrm{~s}$ & $6.15 \mathrm{~s}$ \\
\hline 6 & 96 & $5.82(\mathrm{dm})$ & $5.82(\mathrm{dm})$ & 5 & 97.5 & $6.03(\mathrm{dm})$ & $6.03(\mathrm{dm})$ \\
\hline 8 & 95 & $5.80(\mathrm{dm})$ & $5.80(\mathrm{dm})$ & 7 & 90.5 & $6.17(\mathrm{dm})$ & $6.17(\mathrm{dm})$ \\
\hline $5^{\prime}$ & 114.5 & 6.82 do & 6.82 do & $5^{\prime}$ & 114.5 & 6.90 do & 6.90 do \\
\hline $6^{\prime}$ & 116.5 & 6.93 do & 6.93 do & $6^{\prime}$ & 122.0 & 7.67 do & 7.67 do \\
\hline $2^{\prime \prime}$ & 79 & $\begin{array}{l}5.36 \mathrm{dd} \\
(2.5 / 13)\end{array}$ & $\begin{array}{l}5.36 \mathrm{dd} \\
(2.5 / 13)\end{array}$ & $2^{\prime \prime}$ & 78.5 & $\begin{array}{l}5.52(\mathrm{dd}) \\
(-/ 13)\end{array}$ & $\begin{array}{l}5.42(\mathrm{dd}) \\
(-/ 13)\end{array}$ \\
\hline $3^{\prime \prime} \mathrm{ax}$ & 42 & $\begin{array}{l}3.27 \mathrm{dd} \\
(13 / 17)\end{array}$ & $\begin{array}{l}3.19 \text { dd } \\
(13 / 17)\end{array}$ & $3^{\prime \prime}$ ax & 42 & $\begin{array}{l}3.22 \mathrm{dd} \\
(13 / 17)\end{array}$ & $\begin{array}{l}3.34 \mathrm{dd} \\
(13 / 17)\end{array}$ \\
\hline eq & & $\begin{array}{l}2.57 \mathrm{dd} \\
(3 / 17)\end{array}$ & $\begin{array}{l}2.59 \mathrm{dd} \\
(3 / 17)\end{array}$ & eq & & $\begin{array}{l}2.70(\mathrm{dd}) \\
(-/ 17)\end{array}$ & $\begin{array}{l}2.65(\mathrm{dd}) \\
(-/ 17)\end{array}$ \\
\hline $6^{\prime \prime}$ & 103.5 & - & - & $6^{\prime \prime}$ & 104 & - & - \\
\hline $8^{\prime \prime}$ & 94.5 & $6.00 \mathrm{~s}$ & $6.01 \mathrm{~s}$ & $8^{\prime \prime}$ & 94.5 & $6.07 \mathrm{~s}$ & $6.07 \mathrm{~s}$ \\
\hline $2^{\prime \prime \prime}$ & 114.5 & $\left.6.87 \mathrm{~s}^{*}\right)$ & $\left.6.87 \mathrm{~s}^{*}\right)$ & $2^{\prime \prime \prime}$ & 114.5 & $\left.6.94 \mathrm{~s}^{*}\right)$ & $\left.6.94 \mathrm{~s}^{*}\right)$ \\
\hline $5^{\prime \prime \prime}$ & 115.5 & $6.74 \mathrm{~s}$ & $6.74 \mathrm{~s}$ & $5^{\prime \prime \prime}$ & 115.5 & $6.76-6.82 \mathrm{~m}$ & $6.76-6.82 \mathrm{~m}$ \\
\hline $6^{\prime \prime \prime}$ & 118 & $\left.6.74 \mathrm{~s}^{*}\right)$ & $\left.6.74 \mathrm{~s}^{*}\right)$ & $6^{\prime \prime \prime}$ & 118 & $6.76-6.82 \mathrm{~m}$ & $6.76-6.82 \mathrm{~m}$ \\
\hline
\end{tabular}

*) m-coupling not observable because of broadening of the signals.

earlier results with $P$. cuspidata that contained only $\mathbf{1}$ in reasonable amounts (Seeger et al., 1992). This fact requires some comment. In the first instance one might question the systematic position of the same genus. It must, however, be considered that the flavonoid patterns of mosses may undergo seasonal variations, which may be caused by exogenous and/or endogenous factors. Thus, in fieldstudies, performed over two years, three mosses, which grow close to our campus - two Rhytidiadelphus species and Mnium hornum - showed strong seasonal variations of extractable flavonoids. These variations corresponded with the times of active growth and the amount of light received during this period. Remarkably, different flavonoids responded at such different rates to these factors that a certain compound may be the main constituent at one time and just a trace component at an other time (Brinkmeier et al., 1999). This might also be the case with the two Pilotrichella species, but it was not feasible to study these tropical mosses in this respect.

\section{Experimental}

Pilotrichella flexilis (Hedw.) Angstr. was collected in autumn 1994 at two sites (alt. 2600-2900 m s. m.) in Costa Rica. Vouchers are kept at Herbarium SAAR (Nos 5139 and 5140). Both collections were tested by 2 D-TLC (c. f. Geiger et al., 1997). After they proved to be identical, they were pooled to yield $280 \mathrm{~g}$ of air-dry material. Extraction and isolation was performed as described earlier (Geiger and Markham, 1992; Seeger et al., 1990 and 1992). CC on polyamide- 6 with a $\mathrm{H}_{2} \mathrm{O} / \mathrm{Me}_{2} \mathrm{CO}$ gradient ranging from $0-80 \% \mathrm{MeOH}$ gave five fractions containing $5, \mathbf{3}$, a mixture of $\mathbf{1}+\mathbf{2}+\mathbf{4}$ and an isomer of $\mathbf{6}$, an other isomer of $\mathbf{6}$ and $\mathbf{6}$. CC on Sephadex-LH20 with the eluent was used to remove polymeric impurities from all fractions and separate the components of the mixed fraction. A final clean-up was performed by CC on Sephadex-LH20 with $\mathrm{MeOH} / \mathrm{H}_{2} \mathrm{O}$ (6:4 and 8:2). The yields were $70 \mathrm{mg} \mathrm{\mathbf {1 }}, 70 \mathrm{mg} \mathrm{5}, 56 \mathrm{mg} \mathbf{6}$ and $1-2 \mathrm{mg}$ each of $\mathbf{2 , 3}$, $\mathbf{4}$ and the two unknown isomers of $\mathbf{6}$. 
FAB mass spectra were performed in glycerol as matrix and $4-8 \mathrm{kV} \mathrm{Xe}$.

${ }^{1} \mathrm{H}$ and ${ }^{13} \mathrm{C}$ NMR spectra were recorded at ambient temperature with 500 and $125 \mathrm{MHz}$, respectively.

\section{Acknowledgements}

We are grateful to Professors R. Mues, Universität des Saarlandes, and J. R. Gradstein, Universität Göttingen, for collecting the plant material.

Brinkmeier E. (1996), Phenolische Verbindungen aus Mnium hornum, Leptos tomum macrocarpum und $\mathrm{Pi}$ lotrichella flexilis. Dissertation, Saarbrücken.

Brinkmeier E., Hahn H., Seeger T., Geiger H. und Zinsmeister H. D. (1999), Jahreszeitliche Schwankungen von Flavonoidgehalten in Laubmoosen. Biochemical Systematics and Ecology 27, 427-435.

Geiger H. und Bokel M. (1989), Die Biflavonoidausstattung von Philonotis fontana (Hedw.) Brid. (Bartramiaceae). Z. Naturforsch. 44c, 559-562.

Geiger H. and Markham K. R. (1992), Campylopusaurone, an aurono-flavanone biflavonoid from the mosses Campylopus clavatus and Campylopus holomitrium. Phytochemistry 31, 4325-4328.

Geiger H., Seeger T., Hahn H., Zinsmeister H. D., Markham K. R. and Wong H. (1993), ${ }^{1} \mathrm{H}$ NMR assignments in biflavonoid spectra by proton-detected $\mathrm{C}-\mathrm{H}$ correlation. Z. Naturforsch. 48c, 821-826.

Geiger H., Seeger T., Zinsmeister H. D. and Frahm J.-P. (1997), The occurrence of flavonoids in arthrodontous mosses - an account of the present knowledge. J. Hattori Bot. Lab. 83, 273-308.
We are indepted to Prof. Mues and Drs. Graf, Schuld and Zapp, all Universität des Saarlandes, for performing FAB and NMR spectra respectively. Furthermore we thank Mrs U. Zeitz, Mrs E. Hanck-Huth and Mrs Ch. Zehren for technical assistance and Mrs U. Minnich for typing the manuscript.

Financial support from BASF, Versuchsstation Limburger Hof, is gratefully acknowledged.

Hahn H., Seeger T., Geiger H., Zinsmeister H. D., Markham K. R. and Wong H. (1995), The first biaurone, a triflavone and biflavonoids from two Aulacomnium species. Phytochemistry 40, 573-576.

Rampendahl Ch., Seeger T., Geiger H. and Zinsmeister H. D. (1996), The biflavonoids of Plagiomnium undulatum. Phytochemistry 41, 1621-1624.

Seeger T., Zinsmeister H. D. and Geiger H. (1990), The biflavonoid pattern of Rhytidiadelphus squarrosus (Hedw.) Warnst. Z. Naturforsch. 45c, 583-586.

Seeger T., Geiger H., Frahm J.-P. and Witte L. (1992), 3'3"'-Binaringenin, a new biflavonoid from Pilotrichella cuspidata (Meteoriaceae, Musci). Z. Naturforsch. 47c, 667-669.

Sievers H., Burkhardt G., Becker H. and Zinsmeister H. D. (1992), Hypnogenols and other dihydroflavonols from the moss Hypnum cupressiforme. Phytochemistry 31, 3233-3237.

Sievers H., Burkhardt G., Becker H. and Zinsmeister H. D. (1994), Further biflavonoids and 3'-phenylflavonoids from Hypnum cupressiforme. Phytochemistry 35, $795-798$. 